\title{
FACTORS ASSOCIATED WITH MIDWIFE PERFORMANCE AT COMMUNITY HEALTH CENTER IN EAST JAVA
}

\author{
Anindyah Tri Lhaksmi Kusuma Wardhani1), \\ Didik Tamtomo2), Uki Retno Budihastuti3) \\ 1)Masters Program on Public Health, Universitas Sebelas Maret \\ ${ }^{2)}$ Faculty of Medicine, Universitas Sebelas Maret \\ 3)Department of Obstetrics and Gynecology, Dr. Moewardi Hospital, Surakarta
}

\begin{abstract}
Background: Many complications of pregnancy are avoidable by providing skilled midwifery care during and immediately after childbirth. However, provision of necessary obstetric interventions is often untimely, most likely due to lack of monitoring during labor and postpartum. This study aimed to examine factors associated with midwife performance in early detection of postpartum hemorrhage.

Subjects and Method: A cross sectional study was carried out at 25 community health centers in Banyuwangi, East Java, from February to May 2019. A sample of 200 midwives was selected by simple random sampling. The dependent variable was work performance. The independent variables were age, motivation, training, skill, leadership style, incentive, and human source. The data were collected by questionnaire and analyzed by a multiple logistic regression.

Results: Midwife work performance increased with training $(b=1.46 ; 95 \% \mathrm{CI}=0.48$ to 2.42; $\mathrm{p}=0.003)$, good skill $(\mathrm{b}=2.32 ; 95 \% \mathrm{CI}=1.28$ to $3.36 ; \mathrm{p}=0.001)$, high motivation $(b=1.66 ; 95 \% \mathrm{CI}=0.71$ to $2.61 ; \mathrm{p}=0.001)$, incentive $\mathrm{Rp} 1,000,000(\mathrm{~b}=2.59 ; 95 \% \mathrm{CI}=$ 1.53 to $3.65 ; \mathrm{p}=0.001)$, democratic leadership $(\mathrm{b}=1.95 ; 95 \% \mathrm{CI}=0.93$ to $2.96 ; \mathrm{p}=$ $0.001)$, and number of midwife $>8(b=1.05 ; 95 \% \mathrm{CI}=0.08$ to $2.02 ; \mathrm{p}=0.033)$. It decreased with age $\geq 35$ years old $(b=-1.16 ; 95 \% \mathrm{CI}=-2.16$ to $-0.16 ; \mathrm{p}=0.023$ ).

Conclusion: Midwife work performance increases with training, good skill, high motivation, incentive $\mathrm{Rp}$ 1,000,000, democratic leadership, and number of midwife $>8$. It decreases with age $\geq 35$ years old.
\end{abstract}

Keywords: work performance, leadership style, midwives

\section{Correspondence:}

Anindyah Tri Lhaksmi Kusuma Wardhani. Masters Program on Public Health, Universitas Sebelas Maret. Jl. Ir. Sutami 36A, Surakarta 57126, Central Java, Indonesia. Email: anindyahtri@gmail.com. Mobile: +6285258917339.

The $6^{\text {th }}$ International Conference on Public Health

Best Western Premier Hotel, Solo, Indonesia, October 23-24, 2019 | 262

https://doi.org/10.26911/the6thicph.04.24 